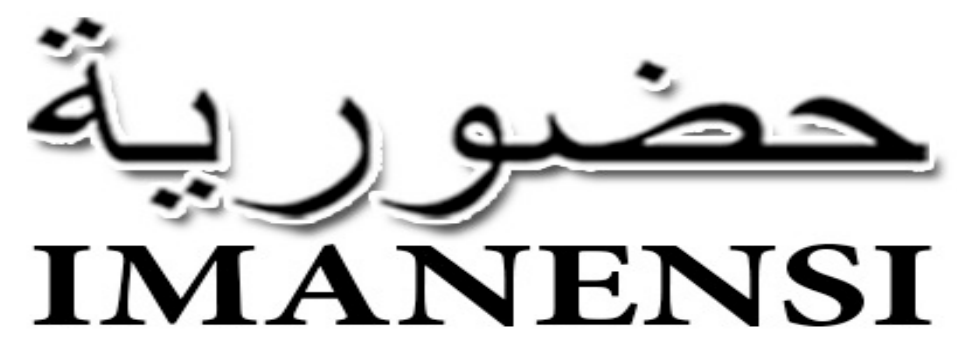

(Jurnal Ekonomi, Manajemen, dan Akuntansi Islam)

Vol 3, No 2, September 2018, Hlmn. 38-47

\title{
Determinan nilai perusahaan
}

\author{
Darti Djuharnia, Vanyah Jessica Rajani ${ }^{\mathrm{b}}$ \\ åb STIE Malangkucecwara, Jl. Terusan Candi Kalasan, Blimbing, \\ Indonesia, 65141 \\ 1*dartidjuharni@yahoo.com
}

doi: 10.34202/imanensi.3.2.2018.38-47

\begin{abstract}
Abstrak
Tujuan penelitian ini adalah untuk mengetahui pengaruh Good Corporate Governance (GCG), profitabilitas, dan leverage terhadap nilai perusahaan. Metode yang digunakan adalah analisis regresi linier berganda dengan jumlah sampel sebanyak 39 dari 13 perusahaan sub sektor pertambangan. Hasil penelitian menunjukkan Good Corporate Governance, yang diproksikan dengan kepemilikan institusional dan kepemilikan managerial, profitabilitas dengan proksi Return On Equity (ROE), dan leverage menggunakan proksi Debt to Equity Ratio (DER) berpengaruh terhadap nilai perusahaan.
\end{abstract}

Kata Kunci: GCG; Profiitabilitas; Leverage.

\section{Abstract}

The purpose of this study is to determine the effect of Good Corporate Governance (GCG), profitability, and leverage on firm value. The method used is multiple linear regression analysis with a total sample of 39 out of 13 mining sub-sector companies. The results of the study indicate Good Corporate Governance, which is proxied by institutional ownership and managerial ownership, profitability with proxy Return On Equity (ROE), and leverage using the proxy Debt to Equity Ratio (DER) to affect the value of the company.

Keywords: GCG; Profitability; Leverage.

This is an open access article under the CC-BY-SA license. 
Penerapan Good Corporate Governance (GCG) bukan lagi menjadi suatu keharusan melainkan menjadi suatu kebutuhan bagi perusahaan-perusahaan dalam menjalankan bisnis (Muliaman, 2012). Penerapan GCG mampu menarik minat investor untuk menanamkan investasinya, dan perbankan dalam memberikan pinjaman pada perusahaan-perusahaan di Indonesia. Dibandingkan dengan negara Asean lainnya, perusahaan di Indonesia memiliki standar penerapan GCG yang lemah, hal tersebut dapat menjadi peran kunci dalam mendorong terjadinya krisis. Oleh karena itu perusahaan harus meningkatkan tata kelola untuk dapat mengatasi krisis yang merupakan salah satu kunci agar terjadi perubahan yang lebih baik bagi perusahaan (sutedi, 2012). Upaya yang dilakukan perusahaan untuk meningkatkan GCG tidak luput dari permasalahan keagenan. Teori keagenan Meckling (1976) menyatakan bahwa perusahaan merupakan hubungan kontrak yang legal antara pemegang saham (principal) dengan manajemen (agent). Dalam hubungan ini sering kali timbul konflik karena adanya perbedaan kepentingan. GCG sebagai suatu sistem tata kelola perusahaan yang baik sangat berperan penting dalam menyeimbangkan perbedaan kepentingan antara pemegang saham dan manajemen perusahaan. Dengan demikian menerapkan progam Good Corporate Governance akan meningkatkan nilai perusahaan(M. \& Priantinah, 2012).

Nilai perusahaan mengacu pada situasi tertentu yang telah dicapai oleh suatu perusahaan (Dianawati, 2013). Nilai perusahaan merupakan gambaran dari kepercayaan masyarakat yang telah melewati proses selama beberapa tahun sejak awal didirikan sampai saat ini. Perusahaan dikatakan berprestasi ketika dapat meningkatkan nilai perusahaan, karena dengan meningkatnya nilai perusahaan, maka para pemilik akan dapat meningkat kesejahteraan anggota organisasinya. Meningkatnya nilai perusahaan dapat dilihat dari efisiensi dan efektifitas tata kelola yang telah dilakukan.

Efektifitas dan efiensi dapat dilihat dari profitabilitas yang dicapai perusahaan. Profitabilitas yang tinggi akan menarik minat investor, dan kondisi tersebut menunjukkan perusahaan tersebut dalam keadaan baik (Syamsudin, 2009). Perusahaan yang memiliki keuntungan yang besar, tidak perlu lagi melakukan pinjaman untuk membantu mendanai operasional, dan hal tersebut yang memengaruhi investor untuk berinvestasi. Berdasarkan uraian sebelumnya, dapat disimpulkan bahwa melaksanakan prinsip tata kelola atau Good Corporate Governance (GCG) yang baik dapat meningkatkan nilai dari perusahaan karena tata kelola yang bagus akan mendorong manajemen untuk bekerja keras mendapatkan keuntungan yang besar. Dengan demikian profitabilitas yang tinggi akan dapat mengurangi leverage yang ada, dan membuat para investor senang untuk melakukan investasi. Beberapa penelitian sebelumnya terkait dengan kajian GCG, profitabilitas, dan leverage antara lain dilakukan oleh Prasetyorini (2013). Hasil penelitiannya menunjukkan bahwa profitabilitas berpengaruh positif terhadap nilai perusahaan dan leverage berpengaruh negatif terhadap nilai perusahaan. Selain itu Tjandra (2015) menyampaikan bahwa GCG memiliki pengaruh negative terhadap profitabilitas, GCG melalui leverage memiliki pengaruh positif namun tidak signifikan terhadap profitabilitas, dan leverage memiliki pengaruh positif terhadap profitabilitas.

Peneliti lain yaitu Rahmadani (2017) menunjukkan variable GCG tidak berpengaruh terhadap nilai perusahaan, profitabilitas berpengaruh terhadap nilai perusahaan, dan variable leverage berpengaruh negative terhadap nilai perusahaan. Septia (2015) meneliti tentang Pengaruh Kinerja Keuangan terhadap Nilai Perusahaan dengan pengungkapan dan Good Corporate Governance sebagai variabel pemoderasi. Dengan variabel Independen yaitu profitabilitas, keputusan investasi, keputusan pendanaan, kebijakkan deviden dan Variabel dependen yaitu nilai perusahaan. Hasil dari penelitiannya menunjukkan bahwa Secara simulatan profitabilitas (ROE), keputusan investasi (PER), keputusan pendanaan (DER), dan kebijakkan deviden (DPR) berpengaruh terhadap nilai perusahaan. Secara parsial profitabilitas (ROE) berpengaruh positif dan signifikan terhadap nilai perusahaan, keputusan investasi (PER) berpengaruh positif dan signifikan terhadap nilai perusahaan, keputusan pendanaan tidak berpengaruh terhadap nilai perusahaan, dan kebijakkan deviden tidak berpengaruh. 
Berdasarkan uraian sebelumnya, peneliti tertarik untuk melakukan penelitian lebih lanjut mengenai pengaruh GCG, profitabilitas, dan leverage terhadap nilai perusahaan. Hal ini dikarenakan hasil-hasil penelitian sebelumnya menunjukkan ketidakkonsistenan sehingga peneliti ingin lebih mengetahui sejauh mana variabel GCG, profitabilitas, dan leverage dapat memengaruhi nilai perusahaan. Oleh karena itu penelitian ini dilakukan dengan tujuan untuk menganalisis pengaruh Good Corporate Governance (GCG), Profitabilitas, dan Leverage terhadap Nilai Perusahaan.

\section{METODE}

Penelitian ini merupakan jenis penelitian kuantitatif untuk mengetahui hubungan atau korelasi antara dua variabel atau lebih dan menjelaskan keterkaitan antara variabel satu dengan variabel yang lain. Penelitian ini dimaksudkan untuk mengetahui adanya korelasi dan pengaruh beberapa variabel dengan melakukan pengujian hipotesis terhadap variabel yang diteliti. Pengujian penelitian ini dilakukan berdasarkan data sekunder. Data tersebut kemudian diolah sehingga diperoleh informasi yang dapat dijadikan kerangka jawaban bagi hipotesis yang telah ditentukan.

Populasi dalam penelitian ini adalah perusahaan sub sektor pertambangan sejumlah 41 perusahaan yang terdaftar di Bursa Efek Indonesia (BEI) dengan periode penelitian tahun 2015-2017. Sampel dalam penelitian ini adalah perusahaan sub sektor pertambangan yang terdaftar di BEI pada periode 2015-2017. Periode yang diteliti selama tiga tahun ini diharapkan akan memberikan data yang valid dan runtun agar diperoleh penelitian yang relevan. Variabel independen yang digunakan dalam penelitian ini adalah GCG, Profitabilitas, dan Leverage kemudian Nilai Perusahaan menjadi variabel dependennya. Metode yang digunakan dalam menentukan sampel adalah metode purposive sampling yang mana pengambilan sampel atas kriteria tertentu berdasarkan ciri-ciri yang sudah diketahui sebelumnya. Jumlah perusahaan yang memenuhi kriteria dalam pemilihan sampel dari penelitian ini dalah 13 perusahaan, sehingga total sampel yang digunakan dalam 3 tahun penelitian sebanyak 39 sampel.

Peneliti juga mengakses secara langsung website resmi dari Bursa Efek Indonesia (BEI) yaitu pada $w w w . i d x . c o . i d$. Bursa Efek Indonesia (BEI) merupakan lembaga resmi yang menyediakan data-data perusahaan pertambangan yang terdaftar di lembaganya. Data yang dimaksud adalah data tentang GCG, Profitabilitas dan Leverage yang ada dalam laporan keuangan tahunan. Variabel penelitian adalah segala sesuatu yang berbentuk apa saja yang ditetapkan oleh peneliti untuk dipelajari sehingga diperoleh informasi tentang hal tersebut, kemudian ditarik kesimpulannya (Sugiyono, 2011:38). Pengukuran kepemilikan manajerial diukur dengan membandingkan jumlah saham yang dimiliki pihak manajemen dengan jumlah saham yang beredar (Sukma \& Perdana, 2014)). Pengukuran kepemilikan institusional diukur dengan membandingkan jumlah saham yang dimiliki institusi dengan jumlah saham yang beredar" (Sukma \& Perdana, 2014). Variabel profitabilitas dalam penelitian ini di proksikan dengan Return On Equity (ROE). ROE diperoleh dari hasil perbandingan antara laba bersih (net income) dengan total ekuitas (equity)(Syamsudin, 2009). Tingkat Leverage dalam penelitian ini diperoleh dari nilai Debt to Equity Ratio (DER). Debt to Equity Ratio dihitung dengan membagi total utang perusahaan (termasuk liabilitas jangka pendek) dengan ekuitas pemegang saham (Horne \& Wachowicz, 2012).

Variabel terikat yang digunakan dalam penelitian ini adalah nilai perusahaan (Y) yang diukur dengan closing price dan rasio Tobin's $Q$. Closing price merupakan harga saham saat penutupan. Closing price dapat diperoleh dari harga terakhir saat saham tersebut berpindah tangan dalam suatu perdagangan. Dalam penelitian ini, untuk memperoleh data yang dibutuhkan penulis menggunakan teknik observasi dokumentasi dikarenakan data berupa data sekunder. Teknik dokumentasi merupakan teknik pengumpulan data dengan cara mempelajari catatan-catatan dokumen. Catatan yang dimaksud adalah laporan keuangan tahunan atau annual report perusahaan pertambangan yang dijadikan sampel. Penelitian ini menggunakan data sekunder berupa laporan keuangan tahunan perusahaan subsektor 
pertambangan yang terdaftar di Bursa Efek Indonesia periode 2015-2017. Data tersebut diperoleh dari www.idx.co.id. Metode analisis data yang digunakan adalah statistic deskriptif yang digunakan untuk menganalisis data dengan cara mendeskripsikan data atau menggambarkan data yang terkumpul sebagaimana adanya. Uji Asumsi Klasik terdiri dari uji normalitas, uji multikolonieritas, uji autokorelasi dan uji heteroskedastisitas. Selain itu penelitian ini juga menggunakan analisis regresi linier berganda, koefisien determinasi (R2) dan untuk uji pengaruh menggunakan uji $\mathrm{F}$ dan uji t.

\section{HASIL DAN PEMBAHASAN}

Sebagaimana disampaikan pada bagian metode sebelumnya, yang menjadi sampel dalam penelitian ini adalah 13 perusahaan. Analisis terhadap tiga belas perusahaan untuk mencapai tujuan penelitian dilakukan melalui laporan keuangan yang publish selama tiga tahun yaitu 2015, 2016, dan 2017. Analisis ini dilakukan dengan beberapa tahapan, yaitu: analisis kepemilikan, analisis profitabilitas, analisis leverage, dan nilai perusahaan.

Analisis Kepemilikan. Tabel 1 menggambarkan kepemilikan manajerial dan institusional untuk 13 perusahaan yang menjadi sampel penelitian ini.

Tabel 1. Tingkat Kepemilikan Perusahaan

\begin{tabular}{cccccccc}
\hline \multirow{2}{*}{ Nomor } & \multirow{2}{*}{$\begin{array}{c}\text { Kode } \\
\text { perusahaan }\end{array}$} & \multicolumn{6}{c}{ Good Corporate Governance } \\
\cline { 3 - 8 } & & $\mathbf{2 0 1 5}$ & $\mathbf{2 0 1 6}$ & $\mathbf{2 0 1 7}$ & $\mathbf{2 0 1 5}$ & $\mathbf{2 0 1 6}$ & $\mathbf{2 0 1 7}$ \\
\cline { 3 - 8 } & ANTM & $\mathbf{0 , 0 0 0 4}$ & 0,0004 & 0,0007 & 0,6500 & 0,6500 & 0,6500 \\
2 & ARTI & 0,1345 & 0,3457 & 0,5527 & $\mathbf{0 , 8 6 5 5}$ & 0,6542 & 0,4472 \\
3 & BUMI & $\mathbf{0 , 7 0 5 7}$ & $\mathbf{0 , 6 7 1 2}$ & $\mathbf{0 , 7 3 7 6}$ & $\mathbf{0 , 2 9 4 2}$ & 0,3287 & $\mathbf{0 , 2 6 2 3}$ \\
4 & CTTH & 0,0657 & 0,0948 & 0,0657 & 0,5221 & 0,5191 & 0,5724 \\
5 & DEWA & 0,6071 & 0,6391 & 0,6981 & 0,3928 & 0,3608 & 0,3018 \\
6 & ELSA & 0,3166 & 0,4399 & 0,4399 & 0,6833 & 0,5600 & 0,5600 \\
7 & HRUM & 0,0001 & $\mathbf{0 , 0 0 0 1}$ & $\mathbf{0 , 0 0 0 1}$ & 0,7200 & 0,7545 & 0,7788 \\
8 & INCO & 0,2049 & 0,2049 & 0,2049 & 0,7950 & $\mathbf{0 , 7 9 5 0}$ & 0,7950 \\
9 & ITMG & 0,0001 & 0,0001 & 0,0009 & 0,7018 & 0,6517 & 0,6514 \\
10 & KKGI & 0,0032 & 0,0034 & 0,0034 & 0,6489 & 0,6488 & 0,6488 \\
11 & PTBA & 0,0006 & 0,0002 & $\mathbf{0 , 0 0 0 1}$ & 0,7106 & $\mathbf{0 , 0 7 0 7}$ & 0,7106 \\
12 & RUIS & 0,2753 & 0,3307 & 0,2753 & 0,3992 & 0,2797 & 0,3223 \\
13 & SMMT & 0,2083 & 0,2685 & 0,1472 & 0,7916 & 0,7314 & $\mathbf{0 , 8 5 2 7}$ \\
\hline
\end{tabular}

Berdasarkan tabel 1, tampak bahwa kepemilikan manajerial pada tahun 2015 memiliki nilai tertinggi pada perusahaan Bumi Resources Tbk (BUMI), dan nilai terendah ditempati oleh perusahaan Aneka Tambang Tbk (ANTM). Tahun 2016 nilai tertinggi terdapat pada perusahan BUMI dan nilai terendah perusahaan Harum Energy Tbk (HRUM). Selanjutnya kepemilikan manajerial tertinggi untuk tahun 2017 terdapat pada perusahaan BUMI, dan terendah perusahaan HRUM. dan Tambang Batubara Bukit Asam Tbk (PTBA). Berdasarkan tabel ini tampak bahwa selama tiga tahun berturut-turut PT BUMI menunjukkan tingkat kepemilikan manajerial yang paling tinggi. Sebagaimana diketahui bahwa kepemilikan manajerial merupakan kepemilikan saham perusahaan dengan tujuan mengurangi konflik keagenan. Konflik keagenan menunjukkan adanya ketidakharmonisan yang terjadi antara pengelola perusahaan dengan pemegang saham. Persentase yang tinggi dari kepemilikan manajerial ini menunjukkan tingkat konflik yang rendah di perusahaan tersebut.

Selanjutnya, kepemilikan Institusional pada tahun 2015 nilai tertinggi adalah Ratu Prabu Energy Tbk (ARTI) dan nilai terendah ditempati oleh BUMI. Tahun 2016 terdapat pada perusahaan Vale Indonesia Tbk (INCO), dan nilai terendah ditempati perusahaan PTBA Selanjutnya tahun 2017 nilai tertinggi perusahaan Golden Eagle Energy Tbk (SMMT) dan nilai terendah oleh perusahaan BUMI. Kepemilikan Institusional merupakan kepemilikan saham oleh investor institusional seperti pemerintah, perusahaan investasi, dan perusahaan swasta lainnya, dengan tujuan 
untuk mengontrol kegiatan manajemen perusahaan agar tidak terjadi penyelewengan. Kepemilikan manajerial dan kepemilikan institusional selaras dengan prinsip dari Good Corporate Governance (GCG) yang mengarahkan dan mengendalikan sebuah perusahaan agar tercapai keseimbangan antara kekuatan dan kewenangan perusahaan dalam memberikan pertanggungjawaban kepada shareholder khususnya, dan stakeholder pada umumnya. Sehingga penerapan GCG yang baik dapat dilihat dari presentase kepemilikan manajerial dan kepemilikan institusionalnya. "Kepemilikan institusional dan kepemilikan manajemen yang besar diyakini dapat membatasi perilaku manajer dalam melakukan manajemen laba" (Guna \& Herawaty, 2010).

Analisis Profitabilitas. Profitabilitas dihitung dengan menggunakan Return On Equity $(R O E)$ yang diperoleh dari perbandingan laba bersih setelah pajak dengan total ekuitas rata-rata kemudian dikalikan $100 \%$. Hasil perhitungan ROE selama tiga tahun tampak pada tabel 2 .

Tabel 2. Tingkat Profitabilitas Perusahaan

\begin{tabular}{ccccc} 
& \multirow{3}{*}{ Nomor } & Kode & \multicolumn{3}{c}{ Profitabilitas } \\
\cline { 3 - 5 } & perusahaan & \multicolumn{3}{c}{ Return On Equity (\%) } \\
\cline { 3 - 5 } 1 & & $\mathbf{2 0 1 5}$ & $\mathbf{2 0 1 6}$ & $\mathbf{2 0 1 7}$ \\
2 & ANTM & $(9,49)$ & 0,35 & 0,74 \\
3 & ARTI & 1,06 & 0,19 & 1,64 \\
4 & BUMI & $\mathbf{7 5 , 2 3}$ & $\mathbf{4 , 3 2 )}$ & $\mathbf{8 4 , 7 7}$ \\
5 & CTTH & 0,67 & 6,63 & 1,47 \\
6 & DEWA & 0,21 & 0,23 & 1,21 \\
7 & ELSA & 14,24 & 10,80 & 8,10 \\
8 & HRUM & $(5,60)$ & 3,76 & 11,44 \\
9 & INCO & 2,75 & 0,10 & $\mathbf{( 0 , 8 4 )}$ \\
10 & ITMG & 7,56 & 14,40 & 26,36 \\
11 & KKGI & 7,45 & 11,44 & 15,39 \\
12 & PTBA & 22,19 & $\mathbf{1 9 , 2 5}$ & 32,90 \\
13 & RUIS & 12,20 & 7,25 & 5,50 \\
& SMMT & $\mathbf{( 1 2 , 5 7 )}$ & $(4,31)$ & 7,41 \\
\hline
\end{tabular}

Berdasarkan tabel 2 dapat disimpulkan bahwa nilai profitabilitas tertinggi pada tahun 2015 terdapat pada perusahaan BUMI dan nilai terendah terdapat pada perusahaan Golden Eagle Energy Tbk (SMMT). Tahun 2016, nilai profitabilitas tertinggi terdapat pada perusahaan PTBA dan nilai terendah pada PT BUMI Kemudian nilai profitabilitas tertinggi untuk tahun 2017 terdapat pada BUMI dan terendah pada perusahaan INCO. Profitabilitas menggambarkan tentang kemampuan sebuah perusahaan untuk memperoleh laba dengan mengerahkan segala kemampuan dan sumber daya yang ada. Semakin tinggi pertumbuhan profitabilitas dari waktu ke waktu dan tingginya ROE menggambarkan semakin baik keadaan suatu perusahaan untuk meningkatkan nilai perusahaan. Pada tabel 3 tersebut PT BUMI menunjukkan profitabilitas yang berfluktuasi khususnya di tahun 2016 saat mengalami kerugian, tetapi tahun 2017 bisa bangkit kembali.

Analisis Leverage. Tingkat leverage perusahaan selama tiga tahun dihitung dengan menggunakan Debt to Equity Ratio (DER) yang diperoleh dari perbandingan total utang dengan total ekuitas. Hasil perhitungan tersebut tampak pada tabel 3, tampak bahwa nilai leverage tertinggi pada tahun 2015 terdapat pada perusahaan Radiant Utama Interinsco Tbk (RUIS) dan nilai terendah ditempati oleh perusahaan HRUM. Tahun 2016 nilai tertinggi ditempati perusahaan RUIS dan nilai terendah perusahaan BUMI. Kemudian nilai leverage tertinggi untuk tahun 2017 terdapat pada perusahaan BUMI dan nilai terendah pada perusahaan HRUM. Sebagaimana diketahui Leverage menunjukkan kemampuan perusahaan dalam menggunakan aktiva dan atau dana yang mempunyai beban tetap (hutang dan atau saham istimewa) dalam rangka mewujudkan tujuan perusahaan untuk memaksimalkan kekayaan perusahaan. 
Semakin tinggi nilai Leverage menandakan semakin buruk pula kinerja keuangan perusahaan karena perusahaan lebih banyak dibiayai oleh pihak di luar perusahaan. Tentu investor lebih menyukai apabila leverage kecil karena laba perusahaan akan banyak digunakan dalam pembagian deviden dibanding angsuran utang dan hal tersebut akan meningkatkan nilai perusahaan

Tabel 3. Tingkat Leverage Perusahaan

\begin{tabular}{ccccc}
\hline & & \multicolumn{3}{c}{ Leverage } \\
\cline { 3 - 5 } Nomor & Kode & \multicolumn{3}{c}{ Debt to Equity Ratio (\%) } \\
\cline { 3 - 5 } & Perusahaan & $\mathbf{2 0 1 5}$ & $\mathbf{2 0 1 6}$ & $\mathbf{2 0 1 7}$ \\
\cline { 3 - 5 } & & 65,73 & 62,87 & 83,96 \\
1 & ANTM & 45,27 & 51,16 & 42,38 \\
2 & ARTI & 216,85 & $\mathbf{( 2 1 1 , 4 0 )}$ & $\mathbf{1 1 9 0 , 9 0}$ \\
3 & BUMI & 109,58 & 95,57 & 117,87 \\
4 & CTTH & 65,95 & 69,39 & 76,57 \\
5 & DEWA & 67,26 & 45,63 & 59,09 \\
6 & ELSA & $\mathbf{1 0 , 8 4}$ & 16,30 & $\mathbf{1 6 , 0 6}$ \\
7 & HRUM & 24,82 & 21,31 & 20,07 \\
8 & INCO & 41,20 & 33,32 & 41,80 \\
9 & ITMG & 28,37 & 16,94 & 18,54 \\
10 & KKGI & 81,90 & 76,04 & 59,33 \\
11 & PTBA & $\mathbf{2 2 2 , 6 1}$ & $\mathbf{1 7 2 , 1 9}$ & 152,27 \\
12 & RUIS & 78,59 & 67,04 & 73,04 \\
13 & SMMT & & & \\
\hline
\end{tabular}

Nilai Perusahaan. Nilai Perusahaan dapat dihitung dengan menggunakan rumus Tobin's $Q$, yaitu Tobin's $Q=\frac{M V E+D}{T A}$. Berdasarkan rumus ini nilai perusahaan selama tiga tahun tampak pada tabel 4.

Tabel 4. Nilai Perusahaan

\begin{tabular}{ccccc}
\hline Nomor & $\begin{array}{c}\text { Kode } \\
\text { Perusahaan }\end{array}$ & \multicolumn{3}{c}{$\begin{array}{c}\text { Nilai Perusahaan } \\
\text { Tobin's Q (decimal) }\end{array}$} \\
\cline { 3 - 5 } & & $\mathbf{2 0 1 5}$ & $\mathbf{2 0 1 6}$ & $\mathbf{2 0 1 7}$ \\
\hline 1 & ANTM & 0,65 & 1,10 & 1,02 \\
2 & ARTI & 0,61 & 0,76 & $\mathbf{0 , 1 9}$ \\
3 & BUMI & $\mathbf{1 , 9 0}$ & $\mathbf{2 , 1 4}$ & 1,28 \\
4 & CTTH & 0,64 & 0,65 & 0,72 \\
5 & DEWA & 0,61 & 0,63 & 0,65 \\
6 & ELSA & 0,81 & 1,04 & 0,93 \\
7 & HRUM & $\mathbf{0 , 4 6}$ & 1,18 & 1,04 \\
8 & INCO & 0,81 & 1,11 & 1,15 \\
9 & ITMG & 0,69 & 1,40 & $\mathbf{1 , 5 8}$ \\
10 & KKGI & 0,51 & 1,31 & 0,39 \\
11 & PTBA & 1,07 & 1,98 & 1,49 \\
12 & RUIS & 0,84 & 0,82 & 0,93 \\
13 & SMMT & 0,52 & $\mathbf{0 , 4 8}$ & 1,01 \\
\hline
\end{tabular}

Berdasarkan tabel 4 ini tampak bahwa pada tahun 2015 nilai tertinggi ditunjukkan oleh perusahaan BUMI dan terendah HRUM. Tahun 2016 nilai tertinggi tampak pada perusahaan BUMI dan terendah pada SMMT. Tahun 2017 tertinggi perusahaan ITMG dan terendah ARTI. Nilai perusahaan merupakan persepsi investor terhadap tingkat keberhasilan perusahaan yang sering dikaitkan dengan harga saham. Memaksimalkan nilai perusahaan sangat penting artinya bagi suatu perusahaan, karena itu berarti juga memaksimalkan kemakmuran stakeholder yang merupakan tujuan utama perusahaan. Nilai perusahaan yang tinggi menunjukan tingkat kepercayaan pasar tidak hanya pada kinerja perusahaan saat ini namun juga pada prospek perusahaan di masa depan, sehingga pasar cenderung untuk 
berinvestasi pada perusahaan. Sebaliknya, jika semakin rendah nilai perusahaan, menunjukan tingkat kepercayaan investor yang rendah untuk berinvestasi.

Langkah selanjutnya setelah dilakukan analisis terhadap laporan keuangan adalah melakukan analisis statistik. Berdasarkan hasil analisis statistik deskriptif yang tampak pada tabel berikut ini, dapat dijelaskan hasilnya sebagai berikut.

Tabel 5. Analisis statistik deskriptif

\begin{tabular}{llllll}
\hline & N & Minimum & Maximum & Mean & $\begin{array}{c}\text { Std. } \\
\text { Deviation }\end{array}$ \\
\hline Kep Manajerial & 39 & 0,0001 & 0,7376 & 0,3260 & 0,1818 \\
Kep Institusional & 39 & 0,0707 & 0,8655 & 0,6161 & 0,1837 \\
ROE & 39 & $-12,57$ & 84077 & 9,6862 & 18,9935 \\
DER & 39 & $-211,40$ & 290,90 & 54,5244 & 85,4024 \\
Tobin's Q & 39 & 0,19 & 2,14 & 1,0049 & 0,5116 \\
\hline
\end{tabular}

Berdasarkan tabel 5 tampak bahwa kepemilikan manajerial yang terbaik ada pada perusahaan BUMI dengan nilai maksimum 0,7376 hal ini juga sejalan dengan hasil analisis laporan keuangan yang ditunjukkan pada tabel 1. Kondisi ini menunjukkan bahwa perusahaan BUMI memiliki tingkat konflik yang sangat rendah atau tingkat keharmonisan yang tinggi dalam pengelolaan perusahaan. Selain analisis statistik deskriptif, dilakukan analisis regresi linear berganda. Dalam penelitian ini analisis regresi linear berganda digunakan untuk memprediksi pengaruh antara variabel independen $(\mathrm{X})$ terhadap variabel dependen $(\mathrm{Y})$. Hasil analisis ini ditunjukkan pada tabel 6 .

Tabe1 - 6 Analisis Regresi Linear Berganda

\begin{tabular}{lll}
\hline & $\mathbf{t}$ & Sig. \\
\hline Kep Manajerial & 2,144 & 0,039 \\
Kep Institusional & 2,232 & 0,032 \\
ROE & 2,076 & 0,046 \\
DER & 2,478 & 0,018 \\
\hline
\end{tabular}

GCG berpengaruh terhadap Nilai Perusahaan. Dari hasil uji parsial (uji t) diperoleh hasil bahwa GCG yang diproksikan oleh Kepemilikan Manajerial memiliki nilai $t$ hitung $>$ t tabel $(2.144>1.854)$ dan nilai signifikasinya $<0.05(0.039<0.05)$, sehingga hasil ini menunjukkan bahwa kepemilikan manajerial berpengaruh positif dan signifikan terhadap nilai perusahaan. kepemilikan manajerial merupakan presentase kepemilikan saham oleh pihak manajemen yang ikut terlibat dalam pengambilan keputusan (direktur,manajer, dan komisaris). Melalui kepemilikan manajerial diharapkan kepentingan pemilik atau pemegang saham akan dapat disejajarkan dengan kepentingan manajer. Jika manajer mempunyai kepemilikan pada perusahaan maka manajer akan bertindak sesuai dengan kepentingan pemegang saham karena manajer juga mempunyai kepentingan di dalamnya.

GCG yang diproksikan oleh kepemilikan Institusional memiliki nilai t hitung > $\mathrm{t}$ tabel $(2.232>1.854)$ dan nilai signifikasinya $<0.05(0.032<0.05)$, sehingga hasil ini menunjukkan bahwa kepemilikan institusional berpengaruh positif dan signifikan terhadap nilai perusahaan. Pemegang saham institusional adalah pemegang saham perusahaan oleh pemerintah, institusi keuangan, institusi berbadan hukum, institusi luar negeri, dana perwalian dan institusi lainnya. Adanya kepemilikan institusional di suatu perusahaan akan mendorong peningkatan pengawasan agar terhadap kinerja manajemen. Semakin besar kepemilikan institusi maka akan semakin besar kekuatan suara dan dorongan dari institusi keuangan tersebut untuk mengawasi manajemen dan akibatnya akan memberikan dorongan yang lebih besar bagi manajemen untuk mengoptimalkan kinerja perusahaan dan menyelaraskan kepentingan manajemen dengan pemegang saham atau stakeholder. Cornett (2006) menyatakan bahwa tindakan pengawasan yang dilakukan oleh sebuah perusahaan dan investor institusional dapat membatasi perilaku manajer. Berdasarkan hasil ini, dapat 
dikatakan bahwa hipotesis pertama yang menyatakan Good Corporate Governance (GCG) berpengaruh terhadap nilai perusahaan diterima.

Sesuai dengan Prinsip GCG yang merupakan pengarah dan pengendali sebuah perusahaan agar tercapai keseimbangan antara kekuatan dan kewenangan perusahaan dalam memberikan pertanggungjawaban kepada shareholder khususnya dan stakeholder pada umumnya. Prinsip GCG selaras dengan tujuan dari kepemilikan manajerial dan kepemilikan institusional, yaitu mengurangi konflik keagenan yang terjadi antara pemegang saham dan pengelola perusahaan dan untuk mengawasi tindakan manajemen dalam memanipulasi pihak institusi. Dengan demikan adanya kepemilikan institusional dapat mengontrol manajemen perusahaan. Apabila perusahaan menerapkan prinsip GCG, maka tata kelola perusahaan akan baik, dan apabila tata kelola perusahaan baik, maka perusahaan tersebut akan mampu menjalankan aktivitas opersionalnya dengan baik pula. Selain itu jika aktivitas operasionalnya berjalan dengan baik, maka perusahaan tersebut mampu untuk meningkatkan nilai perusahaannya. Penelitian ini sejalan dengan Astrini (2015); (M. \& Priantinah, 2012) yang menyatakan bahwa Good Corporate Governance berpengaruh signifikan terhadap nilai perusahaan.

Profitabilitas berpengaruh terhadap Nilai Perusahaan. Hipotesis kedua dalam penelitian ini adalah Profitabilitas berpengaruh terhadap Nilai Perusahaan. Dari hasil uji parsial (uji t) diperoleh hasil Profitabilitas yang diproksikan oleh Return On Equity $(\mathrm{ROE})$ memiliki nilai t hitung $>\mathrm{t}$ tabel $(2.076>1.854$ dan nilai signifikasinya $<0.05$ $(0.046<0.05)$, sehingga hasil ini menunjukkan bahwa Profitabilitas berpengaruh positif dan signifikan terhadap nilai perusahaan. Dari hasil tersebut, dapat dikatakan bahwa hipotesis kedua yang menyatakan bahwa profitabilitas berpengaruh terhadap nilai perusahaan diterima. Secara keseluruhan nilai tertinggi dari ROE terdapat pada perusahaan Bumi Resources dan nilai terendah terdapat pada perusahaan Vale Indonesia. Perusahaan yang memiliki ROE yang tinggi dikarenakan perusahaan tersebut sudah menjalankan operasionalnya dengan baik, memiliki kinerja perusahaan secara efektif dan efisiensi sehingga apa yang dikerjakan perusahaan tersebut mendapatkan hasil yang bagus yaitu tingginya ROE perusahaan. Sedangkan perusahaan yang memiliki ROE yang rendah dikarenakan kurangnya kinerja yang dilakukan perusahaan untuk memperoleh manajemen atau operasional yang baik sehingga laba yang didapat perusahaan rendah.

Return On Equity (ROE) digunakan mengukur keberhasilan perusahaan dalam menghasilkan laba bagi para pemegang saham, sehingga dianggap sebagai respresentasi dari kekayaan pemegang saham atau nilai perusahaan (Mardiyanto, 2008). Semakin tinggi ROE berarti semakin efisien penggunaan modal sendiri yang dilakukan pihak manajemen perusahaan. Profitabilitas yang tinggi akan memberikan sinyal positif bagi investor bahwa perusahaan menghasilkan dalam kondisi yang menguntungkan. Hal ini menjadi daya tarik investor untuk memiliki saham perusahaan. Kenyataannyapara investor menanamkan saham pada perusahaan untuk mendapatkan return, semakin tinggi kemampuan perusahaan memperoleh laba, maka semakin besar return yang diharapkan investor, sehingga menjadikan nilai perusahaan menjadi lebih baik. Permintaan saham yang tinggi akan membuat para investor menghargai nilai saham lebih besar dari pada nilai yang tercatat pada neraca perusahaan. Sehingga Tobin's $Q$ perusahaan tinggi dan nilai perusahaan pun tinggi, dengan demikian maka profitabilitas memiliki pengaruh positif terhadap nilai perusahaan.

Leverage berpengaruh terhadap Nilai Perusahaan. Hipotesis ketiga dalam penelitian ini adalah leverage berpengaruh terhadap nilai perusahaan. Leverage yang diproksikan oleh Debt to Equity Ratio memiliki nilai t hitung $>$ t tabel $(2.478>1.854)$ dan nilai signifikasinya $<0.05(0.018<0.05)$, sehingga hasil ini menunjukkan bahwa leverage berpengaruh positif dan signifikan terhadap nilai perusahaan. Secara keseluruhan nilai tertinggi dari leverage terdapat pada perusahaan Bumi Resources dan nilai terendah terdapat pada perusahaan Harum Energy. Hal tersebut dikarenakan perusahaan tersebut memiliki kinerja keuangan yang buruk, dan kinerja 
manajemen perusahaan dalam mengelola perusahaan masih belum baik. sehingga perusahaan tersebut lebih banyak dibiayai oleh pihak luar perusahaan. Leverage menggambarkan tentang kemampuan perusahaan dalam menggunakan aktiva dan atau dana yang mempunyai beban tetap (hutang dan atau saham istimewa) dalam rangka mewujudkan tujuan perusahaan untuk memaksimisasi kekayaan pemilik perusahaan. Semakin tinggi nilai Leverage menandakan semakin buruk pula kinerja keuanganperusahaan karena perusahaan lebih banyak dibiayai oleh pihak diluar perusahaan. Tentu investor lebih menyukai apabila leverage yang kecil karena laba perusahaan akan banyak digunakan dalam pembagian deviden dibanding angsuran utang dan hal tersebut akan meningkatkan nilai perusahaan.

\section{SIMPULAN}

Penelitian ini ditujukan untuk menganalisis pengaruh Good Corporate Governance (GCG), Profitabilitas, dan Leverage terhadap Nilai Perusahaan. Berdasarkan hasil analisis dapat secara umum dapat disimpulkan bahwa perusahaan BUMI mempunyai nilai perusahaan yang cukup baik. Hal ini tampak dari hasil analisis laporan keuangan dan analisis statistik deskriptif. Dari hasil analisis ini digambarkan perusahaan BUMI memiliki tingkat kepemilikan manajerial yang cukup tinggi, profitabilitas yang tinggi, serta tingkat leverage yang paling rendah di tahun 2016. Gambaran kondisi ini akan menarik minat investor dalam menanamkan sahamnya di perusahaan BUMI. Berdasarkan pengujian hipotesis pertama Good Corporate Governance (GCG) berpengaruh positif dan signifikan terhadap nilai perusahaan. Karena apabila perusahaan menerapkan Good Corporate Governance (GCG), maka tata kelola perusahaan tersebut akan baik, apabila tata kelola perusahaan baik, maka perusahaan tersebut mampu menjalankan aktivitas operasionalnya dengan baik pula. Jika aktivitas operasional perusahaan berjalan dengan baik, maka perusahaan tersebut secara tidak langsung mampu meningkatkan nilai perusahaan.

Pengujian hipotesis kedua profitabilitas berpengaruh terhadap nilai perusahaan. dapat dilihat dari profitabilitas yang diproksikan oleh ROE dengan hasil yang menunjukan bahwa Profitabilitas berpengaruh positif dan signifikan terhadap nilai perusahaan. Profitabilitas yang tinggi akan memberikan sinyal positif bagi investor bahwa perusahaan tersebut dalam kondisi yang menguntungkan. Hal ini menjadi daya tarik investor untuk menanamkan saham pada perusahaan dengan harapan akan mendapatkan return, semakin tinggi kemampuan perusahaan memperoleh laba, maka semakin besar return yang diharapkan investor, sehingga menjadikan nilai perusahaan menjadi lebih baik.

Pengujian hipotesis ketiga leverage berpengaruh terhadap nilai perusahaan. Hal ini dapat dilihat dari leverage yang diprosikan oleh DER dengan hasil yang menunjukan leverage berpengaruh signifikan terhadap niliai perusahaan. Semakin rendah leverage perusahaan maka nilai perusahaan semakin tinggi, jika tinggi nilai leverage menandakan semakin buruk pula kinerja keuangan perusahaan karena perusahaan lebih banyak dibiayai oleh pihak luar perusahaan. Dengan demikian tentu investor lebih menyukai perusahaan dengan tingkat leverage yang rendah, karena laba perusahaan akan digunakan dalam pembagian deviden dibanding melihat perusahaan dengan tingkat leverage yang tinggi dan laba perusahaan akan digunakan untuk mengangsur utang.

Penelitian ini hanya dilakukan pada perusahaan pertambangan, sehingga jika peneliti berikutnya ingin memperluas dan menguji lebih lanjut hasil penelitian ini dapat dilakukan pada perusahaan jenis lain dengan jumlah yang lebih banyak, sehingga akan memperoleh perbandingan yang lebih baik lagi. Selain itu diharapkan peneliti selanjutnya membuat amatan yang lebih lama bukan hanya tiga tahun saja untuk memperoleh hasil yang lebih baik. 


\section{DAFTAR RUJUKAN}

Astrini. (2015). Praktik Good Corporate Governance dan Nilai Perusahaan BUMN di Indonesia Akuntansi Akuntansi, XIX (01), 1-30.

Cornett, e. a. (2006). Earnings Management, Corporate Governance, and True Financial Performance.

Dianawati, C. P. (2013). Pengaruh CSR dan GCG terhadap Nilai Perusahaan: Profitabilitas sebagai Variabel Intervening Ilmu dan Riset Manajemen 5 nomor 1

Guna, W. I., \& Herawaty, A. (2010). Pengaruh Mekanisme Good Corporate Governance, Independensi Auditor, Kualitas Audit Dan Faktor Lainnya Terhadap Manajemen Laba. JURNAL BISNIS DAN AKUNTANSI Volume 12 (nomor 1), 53-68.

Horne, J. C. V., \& Wachowicz, J. M. (2012). Prinsip-Prinsip Manajemen Keuangan buku 1 edisi 13 Salemba Empat

M., R. D. R., \& Priantinah, D. (2012). Pengaruh Good Corporate Governance Dan Pengungkapan Corporate Social Responsibility Terhadap Nilai Perusahaan. Jurnal Nominal / Volume I Nomor I / Tahun 2012, Jurnal Nominal (nomor 1), 84-103.

Mardiyanto, H. (2008). Inti Sari Manajemen Keuangan Jakarta Grasindo

Meckling, M. C. J. d. W. H. (1976). theory of the firm: managerial behavior, agency cost and ownership structure financial economics 3, 4, 305-360.

Muliaman, H. (2012). Good Corporate Governance Bukan Keharusan, Tapi Kebutuhan. Retrieved from http://www.beritasatu.com/pasar-modal/232012gcg-bukan-keharusan-tapi-kebutuhan

Prasetyorini, B. F. (2013). Pengaruh Ukuran Perusahaan, Leverage, Price Earning Ratio dan Profitabilitas terhadap Nilai Perusahaan Ilmu Manajemen 1.

Rahmadani, F. D. (2017). Pengaruh Good Corporate Governance (GCG), Profitabilitas, dan Leverage terhadap Nilai Perusahaan. . Administrasi Bisnis vol 52, No 1.

Septia, W. A. (2015). Pengaruh Profitabilitas, keputusan Investasi, keputusan Pendanaan, dan Kebijakan Deviden terhadap Nilai Perusahaan pada perusahaan Manufaktur yang terdaftar di Bursa Efek Indonesia. skripsi Program Studi Manajemen Fakultas Ekonomi Universitas Negeri Yogyakarta

Sukma, R., \& Perdana, R. (2014). Analisis Pengaruh Corporate Governance terhadap Nilai Perusahaan. Diponegoro Journal of Accounting (Online), vol 3, No.3

sutedi, a. (2012). Good Corporate Governance Jakarta Sinar Grafika

Syamsudin, L. (2009). Manajemen Keuangan Perusahaan. Jakarta: Rajawali Pers.

Tjandra, E. (2015). Pengaruh Good Corporate Governance terhadap Leverage dan Profitabilitas pada Perusahaan property and real estate di Indonesia Gema Aktualita vol 4, no 2 